\title{
Pengembangan paket ipa terpadu berbasisi inkuiri tema peredaran darah manusia untuk meningkatkan kreativitas siswa kelas VIII SMP/MTs
}

\author{
Eka Trisnawati, Supriyono Koes H.*, Metri Dian Insani \\ Universitas Negeri Malang, Jl. Semarang No. 5 Malang, Jawa Timur, Indonesia \\ *Penulis korespondensi, Surel: supriyono.koeshandayanto@um.ac.id
}

Paper received: 01-02-2021; revised: 15-02-2021; accepted: 28-02-2021

\begin{abstract}
The purpose of this research was to produce an integrated science package based on inquiry on human blood circulation theme to improve the creativity of the $8^{\text {th }}$ graders of junior high school. The research used ADDIE (2009) developing model. The result of product development was integrated science package for students and teacher's guideline. Based on the result of feasibility test, 92.53 percent for its content feasibility and 88.96 percent for its presentation feasibility which meant very feasible, it was predicted that the product feasibility in improving students creativity was 85.00 percent which meant very feasible. Feasibility test of teacher's guideline the percentage of content and presentation feasibility was 88.96 percent which meant very feasible. On the readable test, it was obtained 89.94 percent which meant very feasible. Based on those result, science package must be tested wildely for feasibility.
\end{abstract}

Keywords: science package; inquiry; creativity; human blood circulation

\begin{abstract}
Abstrak
Tujuan penelitian ini adalah menghasilkan produk Paket IPA Terpadu berbasis inkuiri tema peredaran darah manusia untuk meningkatkan kreativitas siswa kelas VIII SMP/MTs. Penelitian ini merupakan penelitian pengembangan yang dilakukan dengan model pengembangan ADDIE (2009). Hasil dari penelitian ini adalah Paket IPA Terpadu untuk siswa dan Panduan Guru. Hasil validasi menunjukkan bahwa uji kelayakan isi dan kelayakan penyajian Paket IPA Terpadu memperoleh persentase sebesar 92,53 persen dan 88,96 persen dengan kriteria sangat layak, prediksi kemampuan Paket IPA Terpadu untuk meningkatkan kreativitas memperoleh persentase sebesar 85,00 persen dengan kriteria sangat layak. Uji kelayakan Panduan Guru memperoleh persentase sebesar 88,96 persen. Berdasarkan uji keterbacaan terbatas yang dilakukan, rata-rata nilai persentase yang diperoleh adalah 84,94 persen. Berdasarkan hasil yang diperoleh, agar Paket IPA Terpadu layak digunakan perlu diadakan uji coba lapangan secara luas.
\end{abstract}

Kata kunci: paket IPA terpadu; inkuiri; kreativitas; peredaran darah manusia

\section{Pendahuluan}

Kurikulum yang digunakan dalam sistem pendidikan Indonesia saat ini adalah kurikulum 2013. Berdasarkan Permendikbud Nomor 68 Tahun 2013 mengenai proses pembelajaran IPA untuk jenjang SMP/MTs dilaksanakan dengan terpadu dengan mengintegrasikan konten biologi, fisika, dan kimia. Penelitian yang telah dilaksanakan oleh Rizqi, dkk. (2013: 205-206) menyatakan bahwa penggunaan pembelajaran terpadu membuat penyampaian materi dapat diterima siswa dengan baik sehingga pembelajaran dapat diserap dengan mudah.

Berdasarkan studi lapangan yang dilakukan di SMP di kota Malang, didapatkan bahwa bahan ajar IPA yang digunakan dalam pembelajaran kurang terpadu sehingga guru mengalami kesulitan dalam membelajarkan materi IPA secara terpadu. Penelitian Trian, dkk. (2013: 270) menyatakan bahwa bahan ajar IPA yang digunakan dalam proses belajar 
mengajar sudah terpadu tetapi konten didalamnya masih terpisah-pisah. Menurut Utami, dkk. (2014: 571) dalam penelitiannya juga menemukan bahwa bahan ajar IPA ternyata belum dapat memadukan materi dengan baik. Berdasarkan penjelasan tersebut dapat disimpulkan bahwa pembelajaran IPA belum dapat dilaksanakan secara terpadu dikarenakan minimnya bahan ajar. Hal tersebut dapat diatasi salah satunya dengan mengembangkan paket IPA terpadu.

Paket IPA Terpadu merupakan bahan ajar yang didalamnya terdapat konsep IPA yang diintegrasi secara menyeluruh. Penelitian Koes H., dkk. (2010) menunjukkan bahwa guru IPA SMP di Malang Raya membutuhkan Paket IPA Terpadu dan panduan guru untuk menumbuhkan kompetensi siswa. Pengembangan Paket IPA Terpadu yang telah ada ialah pengembangan dengan menggunakan kurikulum 2006 dan berbasis konstruktivisme (Bachtiar, 2010; Koes H., dkk., 2010). Berdasarkan hal tersebut, maka perlu dikembangkan bahan ajar yang sesuai dengan kurikulum yang berlaku saat ini yaitu kurikulum 2013 dengan pembelajaran berbasis inkuiri. Menurut penelitian yang dilakukan oleh Widiadnyana, dkk. (2014) serta Kristin, dkk. (2015), penggunaan pembelajaran inkuiri dapat membantu siswa untuk lebih menguasai materi.

Pembelajaran inkuiri berkaitan dengan kreativitas yang dimiliki siswa. Munandar (1987: 85) menyatakan bahwa kreativitas berkaitan dengan inkuiri saat siswa diminta untuk mengajukan pertanyaan dan memberikan hipotesis, serta saat menggabungkan fakta yang diketahui dalam menyelesaikan suatu permasalahan. Menurut penelitian Sugiarto dan Djakri (2015: 2) semakin besar kemampuan siswa dalam menyelesaikan masalah maka pengalaman belajar siswa juga semakin bertambah sehingga mampu meningkatkan kreativitas siswa.

Salah satu materi pembelajaran IPA adalah sistem peredaran darah manusia. Materi ini memuat konsep tentang komponen darah, organ dan sistem peredaran darah, tekanan darah, serta gangguan peredaran darah. Penelitian Khairani dan Yulina, (2014) serta Utami, dkk. (2014) menyatakan bahwa masih terdapat 60\% siswa yang memiliki nilai kurang dari kriteria kelulusan minimum (KKM) pada materi tersebut. Banyaknya siswa yang memiliki nilai kurang dari KKM mengindikasikan bahwa pokok bahasan tersebut sulit untuk dipahami, sehingga perlu dikembangkan bahan ajar yang diperkaya dengan permainan edukatif dan kegiatan langsung agar memudahkan siswa memahami materi peredaran darah manusia.

Berdasarkan uraian di atas, peneliti bermaksud melakukan penelitian dengan judul "Pengembangan Paket IPA Terpadu Berbasis Inkuiri Tema Peredaran Darah Manusia untuk Meningkatkan Kreativitas Siswa Kelas VIII SMP/MTs".

\section{Metode}

Penelitian ini menggunakan model penelitian ADDIE (Branch: 2009) yang terdiri dari 5 tahap, Analyze (analisis), Design (perancangan), Develop (pengembangan), Implementation (implementasi), dan Evaluation (evaluasi). Pada penelitian dan pengembangan ini, tahap implementation tidak dilaksanakan sepenuhnya dan hanya berupa validasi dari pakar dan uji coba keterbacaan terbatas serta hanya melakukan tahap evaluation berupa evaluasi formatif. Tahap analyze dilakukan untuk mendefinisikan hal-hal yang akan dipelajari oleh siswa, meliputi beberapa kegiatan, yaitu analisis kebutuhan dan analisis kerja. Tahap design dilakukan untuk menyiapkan produk yangn dikembangkan, terdiri dari kegiatan perumusan tujuan umum pembelajaran yang dapat diukur, pemilihan materi atau isi pembelajaran, pemilihan kegiatan siswa, pemilihan media pembelajaran, dan perencanaan proses penilaian. 
Tahap develop meliputi menyiapkan bahan sesuai dengan spesifikasi produk yang dikembangkan dan merealisasikan rancangan produk. Tahap implementation meliputi penggunaan produk pengembangan untuk diaplikasikan, berupa validasi atau uji kelayakan kepada pakar serta uji keterbacaan skala kecil atau terbatas pada siswa. Tahap evaluation meliputi evaluasi formatif dan evaluasi sumatif, namun pada penelitian ini dilakukan evaluasi formatif karena evaluasi ini berhubungan dengan tahapan penelitian penngembangan yaitu memperbaiki produk yang dihasilkan berdasarkan hasil validasi.

Desain uji coba penelitian ini meliputi kegiatan valiadasi dan uji keterbacaan terbatas. Validasi dilakukan oleh dosen dan guru IPA SMP untuk mengetahui kelayakan Paket IPA Terpadu, kelayakan Panduan Guru, dan penilaian ahli tentang kemampuan Paket IPA Terpadu meningkatkan kreativitas siswa. Uji coba keterbacaan terbatas dilakukan oleh siswa SMP kelas VIII yang telah mendapatkan materi sistem peredaran darah manusia.

Data yang diperoleh dari validasi dan uji keterbacaan berupa data kuantitatif dan data kualitatif. Data kuantitatif merupakan data yang diperoleh berdasarkan skor yang terdapat pada angket uji kelayakan. Data kualitatif merupakan data yang diperoleh berdasarkan kritik, tanggapan dan saran yang terdapat dalam angket uji kelayakan. Data dikumpulkan menggunakan instrumen berupa angket meliputi angket uji kelayakan Paket IPA Terpadu, angket uji kelayakan Panduan Guru Paket IPA Terpadu dan angket uji coba keterbacaan terbatas. Angket validasi menggunakan skala Likert kemudian data yang diperoleh dianalisis menggunakan analisis deskriptif untuk data kualitatif dan teknik penghitungan rata-rata untuk data kuantitatif. Berdasarkan hasil analisis dapat diketahui tingkat kelayakan Paket IPA Terpadu dengan acuan persentase tingkat kriteria validasi untuk data hasil validasi Arikunto (2012: 281) yang disajikan pada Tabel 1.

Tabel 1. Tingkat Kriteria Validasi untuk Analisis Data Hasil Validasi

\begin{tabular}{ll}
\hline Persentase (\%) & Kriteria \\
\hline $30-39$ & Tidak baik/ tidak layak (revisi total) \\
$40-55$ & Kurang baik/ kurang layak (revisi) \\
$56-65$ & Cukup baik/ cukup layak \\
$66-79$ & Baik/ layak \\
$80-100$ & Sangat baik/ sangat layak \\
\hline
\end{tabular}

\section{Hasil dan Pembahasan}

\section{Hasil Penilaian}

Hasil penilaian Paket IPA Terpadu dari para validator berupa data kuantitatif dan data kualitatif. Data kuantitatif didapatkan dari perolehan skor angket yang dikonversikan ke dalam bentuk nilai validitas untuk mengetahui tingkat kevalidan Paket IPA Terpadu. Kevalidan tersebut diperoleh dari uji kelayakan isi dan kelayakan penyajian Paket IPA Terpadu yang kemudian dianalisis per aspek. Nilai dan kriteria hasil uji kelayakan per aspek dalam Paket IPA Terpadu dapat dilihat pada Tabel 2. dan Tabel 3. 
Tabel 2. Hasil Analisis Uji Kelayakan Isi Paket IPA Terpadu Berbasis Inkuiri Tema Peredaran Darah Manusia

\begin{tabular}{lllll}
\hline No & Aspek yang dinilai & Rerata & Persentase & Kriteria \\
\hline 1. & Keluasan Materi & 4,67 & $93,33 \%$ & Sangat Layak \\
2. & Kedalaman Materi & 4,50 & $90,00 \%$ & Sangat Layak \\
3. & Keakuratan Fakta dan Konsep & 4,55 & $90,95 \%$ & Sangat Layak \\
4. & Keakuratan Ilustrasi & 4,67 & $93,33 \%$ & Sangat Layak \\
5. & Kesesuaian dengan Perkembangan Ilmu & 4,78 & $95,56 \%$ & Sangat Layak \\
6. & Berbasis Inkuiri & 4,60 & $92,00 \%$ & Sangat Layak \\
\hline & Nilai Rata-Rata & 4,63 & $92,53 \%$ & Sangat Layak \\
\hline
\end{tabular}

Tabel 3. Hasil Analisis Uji Kelayakan Penyajian Paket IPA Terpadu Berbasis Inkuiri Tema Peredaran Darah Manusia

\begin{tabular}{lllll}
\hline No & Aspek yang dinilai & Rerata & Persentase & Kriteria \\
\hline 1. & Teknik Penyajian & 4,67 & $93,33 \%$ & Sangat Layak \\
2. & Penyajian Pembelajaran & 4,25 & $85,00 \%$ & Sangat Layak \\
3. & Kelengkapan Penyajian & 4,45 & $89,02 \%$ & Sangat Layak \\
\hline & Nilai Rata-Rata & 4,46 & $89,29 \%$ & Sangat layak \\
\hline
\end{tabular}

Hasil analisis rata-rata presentase nilai uji kelayakan isi Paket IPA Terpadu adalah 92,53\% dan uji kelayakan penyajian Paket IPA Terpadu adalah 89,92\%. Hasil ini menunjukkan bahwa Paket IPA Terpadu memenuhi kriteria sangat layak. Hal tersebut menunjukkan bahwa Paket IPA Terpadu yang dikembangkan sangat layak digunakan dalam pembelajaran.

Data kualitatif yang diperoleh dari kegiatan validasi berupa tanggapan, kritik dan saran yang dijadikan sebagai bahan untuk melakukan revisi. Tanggapan, kritik dan saran terhadap Paket IPA Terpadu antara lain, 1) pada bagian keluasan materi perlu ditambah tentang KI 1 dan 2; 2) pada bagian keakuratan materi terdapat pemilihan pemilihan kata sedikit kurang tepat untuk menuntun siswa membuat hipotesis; dan 3) pada bagian cover, pemilihan gradasi warna pada cover lebih baik yang menyatu serta gambar bangunan tidak berhubungan dengan materi

IPA terpadu yang dikembangkan merupakan paket berbasis inkuiri yang dalam setiap tahapannya menjadikan siswa sebagai pusat dari pembelajaran. Dampak yang diharapkan muncul setelah siswa menggunakan Paket IPA Terpadu ini adalah meningkatkan kreativitas siswa. Kreativitas siswa yang diharapkan yaitu siswa mampu mencerminkan kelancaran, keluwesan, dan orisinalitas dalam berfikir serta kemampuan mengelaborasi suatu gagasan. Hal tersebut dapat diperoleh dari kegiatan mengamati video, merancang hipotesis, merancang kalimat, dan menyimpulkan percobaan.

Untuk mengukur kreativitas siswa, seharusnya dilakukan dengan uji keterlaksanaan pembelajaran. Pada penelitian pengembangan ini hanya dilakukan sampai pada tahap uji keterbacaan, dikarenakan keterbatasan waktu, biaya, dan tenaga peneliti, sehingga aspek hubungan pembelajaran berbasis inkuiri mampu meningkatkan kreativitas siswa setelah belajar menggunakan paket yang telah dikembangkan dapat diketahui dari penilaian oleh validator. Hasil penilaian oleh valildator tentang kemampuan Paket IPA Terpadu 
meningkatkan kreativitas siswa berupa data kuantitatif dan data kualitatif. Data kuantitatif didapatkan dari perolehan skor angket yang dikonversikan ke dalam bentuk nilai validitas untuk mengetahui tingkat kevalidan kemampuan Paket IPA Terpadu dalam meningkatkan kreativitas siswa. Kevalidan tersebut diperoleh dari penilaian ahli tentang kemampuan Paket IPA Terpadu untuk meningkatkan kreativitas siswa yang kemudian dianalisis per aspek. Nilai dan kriteria hasil penilaian ahli tentang kemampuan Paket IPA Terpadu untuk meningkatkan kreativitas siswa dapat dilihat pada Tabel 4.

Tabel 4. Hasil Analisis Penilaian Ahli tentang Kemampuan Paket IPA Terpadu untuk Meningkatkan Kreativitas Siswa

\begin{tabular}{|c|c|c|}
\hline Aspek yang dinilai & Rerata & Persentase \\
\hline Penyajian masalah yang relevan untuk mendorong & & \\
\hline $\begin{array}{l}\text { kemampuan siswa memberikan gagasan/ jawaban yang benar } \\
\text { sebanyak-banyaknnya }\end{array}$ & 4,33 & $86,67 \%$ \\
\hline $\begin{array}{l}\text { Mendorong kemampuan siswa untuk menggunakan pemikiran } \\
\text { yang berbeda dalam menyelesaikan masalah }\end{array}$ & 4,33 & $86,67 \%$ \\
\hline $\begin{array}{l}\text { Mendukung siswa untuk menjawab masalah dengan jawaban } \\
\text { berbeda/ unik }\end{array}$ & 4,00 & $80,00 \%$ \\
\hline $\begin{array}{l}\text { Mendorong siswa memberikan pemecahan masalah secara } \\
\text { rinci dan detail }\end{array}$ & 4,33 & $86,67 \%$ \\
\hline Nilai Rata-Rata & 4,25 & $85,00 \%$ \\
\hline
\end{tabular}

Data kualitatif yang diperoleh dari kegiatan validasi berupa tanggapan, kritik dan saran yang dijadikan sebagai bahan untuk melakukan revisi. Tanggapan, kritik dan saran terhadap penilaian para ahli tentang kemampuan Paket IPA Terpadu untuk meningkatkan kreativitas antara lain, 1) aspek penyajian masalah yang relevan untuk mendorong kemampuan siswa mengemukakan gagasan yaitu siswa sudah didorong dan diberi kesempatan untuk mengemukakan gagasan dan 2) mendukung siswa memberikan gagasan yang berbeda dan unik yaitu pemberian dorongan dalam bentuk kata-kata cukup mendukung siswa memberikan gagasan berbeda dan unik.

Hasil penilaian dari validator menunjukkan bahwa aspek hubungan pembelajaran inkuiri mampu meningkatkan kreativitas siswa memperoleh nilai rata-rata presentase sebesar $85,00 \%$ dengan kriteria sangat layak. Hal tersebut menunjukkan bahwa Paket IPA Terpadu ini sangat layak digunakan dalam pembelajaran dan mampu meningkatkan kreativitas siswa.

Hasil penilaian Panduan Guru dari para validator berupa data kuantitatif dan data kualitatif. Data kuantitatif didapatkan dari perolehan skor angket yang dikonversikan ke dalam bentuk nilai validitas untuk mengetahui tingkat kevalidan Panduan Guru. Kevalidan tersebut diperoleh dari uji kelayakan Panduan Guru yang kemudian dianalisis per aspek. Nilai dan kriteria hasil uji kelayakan per aspek dalam Panduan Guru dapat dilihat pada Tabel 5. 
Tabel 5. Hasil Analisis Uji Kelayakan Panduan Guru Paket IPA Terpadu Berbasis Inkuiri Tema Peredaran Darah Manusia

\begin{tabular}{lllll}
\hline No & Aspek yang dinilai & Rerata & Persentase & Kriteria \\
\hline 1. & Kesesuaian Materi dengan Kebutuhan & 4,33 & $86,67 \%$ & Sangat Layak \\
2. & Guru & 4,44 & $88,89 \%$ & Sangat Layak \\
3. & Kelengajian & 4,47 & $89,93 \%$ & Sangat Layak \\
\hline & Nilai Rata-Rata & 4,45 & $88,96 \%$ & Sangat Layak \\
\hline
\end{tabular}

Hasil analisis rata-rata presentase nila uji kelayakan Panduan Guru adalah 88,96\% Hasil ini menunjukkan bahwa Panduan Guru memenuhi kriteria sangat layak. Hal tersebut menunjukkan bahwa Panduan Guru yang dikembangkan sangat layak digunakan dalam pembelajaran.

Data kualitatif yang diperoleh dari kegiatan validasi berupa tanggapan, kritik dan saran yang dijadikan sebagai bahan untuk melakukan revisi. Tanggapan, kritik dan saran terhadap Panduan Guru Paket IPA Terpadu antara lain, 1) aspek strategi pembelajaran yaitu terdapat penjelasan kurang dapat dimengerti. Seperti kata "Paket IPA Terpadu ini disusun berbasis inkuiri. Setiap pembelajaran diawali dengan suatu kegiatan ........” dan 2) aspek teknik penilaian yaitu pada Tabel penilaian kinerja ilmiah dan keterangan penilaiannya kurang jelas. Selain itu juga tidak ada kriteria penilaiannya.

\section{Hasil Uji Coba Kelompok Kecil}

Uji coba kelompok kecil atau uji keterbacaan terbatas bertujuan untuk mengetahui keterbacaan produk yang dikembangkan. Uji keterbacaan dilaksanakan di SMP Negeri 8 Malang kelas VIII C dengan jumlah 10 siswa yang memiliki kemampuan kognitif berbeda. Hasil uji keterbacaan terbatas berupa data kuantitatif dan data kualitatif. Data kuantitatif didapatkan dari perolehan skor angket yang dikonversikan ke dalam bentuk nilai validitas. Nilai dan kriteria hasil uji keterbacaan terbatas per aspek dalam Paket IPA Terpadu dapat dilihat pada Tabel 6.

Tabel 6. Hasil Analisis Uji Keterbacaan Terbatas

\begin{tabular}{cllll}
\hline No & Aspek yang dinilai & Rerata & Persentase & Kriteria \\
\hline 1. & Cover Buku & 4,15 & $83,00 \%$ & Sangat Layak \\
2. & Sistematika Paket & 3,90 & $78,00 \%$ & Layak \\
3. & Daftar Isi & 4,55 & $91,00 \%$ & Sangat Layak \\
4. & Peta Konsep & 4,50 & $90,00 \%$ & Sangat Layak \\
5. & Apersepsi & 4,20 & $84,00 \%$ & Sangat Layak \\
6. & Kegiatan Siswa & 4,10 & $82,00 \%$ & Sangat Layak \\
7. & Uraian Materi & 4,20 & $84,00 \%$ & Sangat Layak \\
8. & Rangkuman & 4,40 & $88,00 \%$ & Sangat Layak \\
9. & Aplikasi Konsep & 4,15 & $83,00 \%$ & Sangat Layak \\
10. & Uji Pemahaman & 4,05 & $81,00 \%$ & Sangat Layak \\
11. & Glosarium & 4,30 & $86,00 \%$ & Sangat Layak \\
12. & Manfaat & 4,47 & $89,33 \%$ & Sangat Layak \\
\hline & Nilai rata-rata & 4,25 & $84,94 \%$ & Sangat Layak \\
\hline
\end{tabular}


Data kualitatif yang diperoleh dari kegiatan validasi berupa tanggapan, kritik dan saran yang dijadikan sebagai bahan untuk melakukan revisi. Tanggapan, kritik dan saran siswa terhadap Paket IPA Terpadu antara lain 1) pada bagian halaman depan pemilihan covernya cukup menarik dan pada bagian sistematika paket sangat mudah dipahami karena terdapat penjelasan yang berada di samping kiri gambar.

Berdasarkan hasil analisis terhadap data kuantitatif uji keterbacaan diketahui bahwa produk yang dikembangkan mememnuhi kriteria sangat layak. Sebagian besar siswa memberikan penilaian positif terhadap Paket IPA Terpadu yang dikembangkan. Data kualitatif berupa tanggapan, kritik, dan saran yang diberikan oleh siswa menunjukkan bahwa sebagian besar siswa memberikan komentar yang baik. Oleh karena itu, Paket IPA Terpadu ini layak untuk digunakan di dalam pembelajaran.

\section{Simpulan}

\section{Kesimpulan}

Penelitian ini menghasilkan Paket IPA Terpadu dan Panduan Guru berbasis inkuiri tema peredaran darah manusia untuk meningkatkan kreativitas siswa kelas VIII SMP/MTs. Kegiatan pembelajaran pada Paket IPA Terpadu ini disajikan dengan menggunakan pembelajaran berbasis inkuiri dan diprediksi dapat meningkatkan kreativitas siswa.

Berdasarkan hasil analisis validasi yang telah dilakukan diperoleh rata-rata nilai presentase kelayakan isi dan penyajian Paket IPA Terpadu sebesar 92,53\% dan 89,92\%, prediksi kemampuan Paket IPA Terpadu untuk meningkatkan kreativitas sebesar 85,00\%, kelayakan Panduan Guru sebesar 88,96\%, dan uji keterbacaan terhadap paket sebesar $84,94 \%$. Berdasarkan hasil validasi dan uji keterbacaan dapat disimpulkan bahwa Paket IPA Terpadu yang dikembangkan memenuhi kriteria sangat layak. Untuk menunjukkan Paket IPA Terpadu layak digunakan dalam pembelajaran perlu diadakan uji coba lapangan secara luas.

\section{Saran}

Saran yang diberikan pada penelitian selanjutnya adalah mencari dan memperbannyak referensi tentang desain agar tampilan produk lebih menarik, melakukan uji coba lebih lanjut atau uji coba lapangan untuk menguji efektivitas dan kelayakan Paket IPA Terpadu dalam meningkatkan kreativitas pada proses pembelajaran dan diadakan penelitian dan pengembangan paket IPA Terpadu pada materi-materi lain.

\section{Daftar Rujukan}

Bachtiar, R. W. (2010). Pengembangan paket IPA terpadu berbasis konstruktivisme dengan tema peredaran darah untuk siswa kelas VIII di SMP Negeri 20 Malang (Doctoral dissertation, Universitas Negeri Malang).

Branch, Robert Maribe. (2009). Instructional Design: The ADDIE Approach. USA: Department of Educational Psychology and Instructional Technology University of Georgia

Khairani, L.R. dan Yulina, A.F. (2014). Pengaruh Model Pembelajaran Kooperatif Tipe Team Assisted Individualization (TAI) Terhadap Hasil Belajar Biologi Siswa Kelas Xi Pada Materi Sistem Peredaran 
Darah Manusia MA PP. Hasanatul Barokah Tambusai Rokan Hulu Tahun Pembelajaran 2014/2015. Jurnal Ilmiah Mahasiswa FKIP Prodi Biologi. (Online), 1 (1) (2015)

Koes H., S., Imam P., T., dan Parlan. (2010). Pengembangan Paket IPA Terpadu Berbasis Konstruktivisme Untuk Menumbuhkan Kompetensi Siswa. Laporan Penelitian Hibah Bersaing.

Munandar, S. U. (1987). Mengembangkan bakat dan kreativitas anak sekolah: penuntun bagi guru dan orang tua. Penerbit PT. Gramedia, Jakarta.

Nyeneng, I. D. P., \& Ertikanto, C. (2015). Pengembangan Modul Pembelajaran Berbasis Inkuiri Terbimbing Pada Materi Elatisitas Dan Hukum Hooke. Jurnal Pembelajaran Fisika, 3(1).

Pendidikan, K., \& Indonesia, K. R. (2013). Peraturan Menteri Pendidikan dan Kebudayaan No. 68 tahun 2013 tentang Kerangka Dasar Dan Struktur Kurikulum Sekolah Menengah Pertama/Madrasah Tsanawiyah. PERMENDIKBUD,(Jakarta, Kemendikbud). Jakarta: Kemdikbud.

Prestasi, M., \& Akuntansi, P. B. (2014). Arikunto, Suharsimi. 2012. Dasar-Dasar Evaluasi Pendidikan. Jakarta: Bumi Aksara. Universitas, 137, 142.

Rizqi, A., Parmin, P., \& Nurhayati, S. (2013). Pengembangan modul IPA terpadu berkarakter tema pemanasan global untuk siswa SMP/MTs. Unnes Science Education Journal, 2(1).

Sugiarto, A., \& Djukri, D. (2015). Pembelajaran berbasis SETS sebagai upaya meningkatkan kreativitas dalam pemecahan masalah pencemaran lingkungan. Jurnal Inovasi Pendidikan IPA, 1(1), 1-11.

Trian, E. A., Haryani, S., \& Sedyawati, S. M. R. (2013). Pengembangan Modul IPA Terpadu Berkarakter pada Tema Pengelolaan Lingkungan untuk Kelas VII SMP. Unnes Science Education Journal, 2(2).

Utami, F. N., Ridlo, S., \& Widiyatmoko, A. (2014). Pengembangan Lks Ipa Terpadu Berbasis Permainan Edukatif Tema Tekanan Dalam Sistem Peredaran Darah Manusia Untuk Siswa Kelas VIII. Unnes Science Education Journal, 3(3).

Widiadnyana, I. W., Sadia, I. W., \& Suastra, I. W. (2014). Pengaruh model discovery learning terhadap pemahaman konsep IPA dan sikap ilmiah siswa SMP. Jurnal Pendidikan dan Pembelajaran IPA Indonesia, 4(2). 